\title{
From boots on the ground to followers in the sky: Volunteer mobilization and populist rhetoric in the presidential campaigns of Barack Obama and Donald Trump
}

\author{
Anne Mørk \\ $\mathrm{PhD}$, Independent scholar
}

\begin{abstract}
The article analyzes the presidential campaigns of Barack Obama and Donald Trump, with particular focus on their respective uses of the internet and social media communication in mobilizing voters and volunteers and using their way of connecting with voters to emphazise their legitimacy as anti-elitist candidates. In his 2008 campaign, Obama set the precedent for using online strategies to build and support a national movement within the framework of the Democratic Party, Trump, an outsider in the GOP, took the strategy a step further and used social media as his primary tool of voter communication and mobilization with only emphasized his populist message. In their use of online campaigns, both Trump and Obama relied in populism rhetorical tools, though from different sides of the political spectrum, adding to contemporary debates of the nature and purpose of populism in the twenty-first century. However, in both candidates' campaigns mobilization of volunteers through their respective national movement became symbols of their populist appeals,
\end{abstract}

Keywords: Donald Trump, Barack Obama, presidential campaigns, populism, volunteerism, online campaigning

Polls leading up to the 2016 presidential election strongly suggested that Democratic candidate Hillary Clinton would become the forty-fifth presi- 
dent of the United States. ${ }^{1}$ A dominant narrative in the US media, implying the weakness of the Trump candidacy and a probable Clinton victory, was Trump's lack of campaign organization and his weak "ground game." 2 The Republican voters' choice of business tycoon and reality-tv star Donald Trump as their candidate seemed to tip the odds in Clinton's favor. Trump displayed several traits that would usually weaken the candidacy of most other politicians: seemingly racist statements (politically dangerous at a time when non-white voters were a growing demographic), a history of alleged sexual harassment and a complete lack of political experience. The electoral victories of Barack Obama in 2008 and 2012 had set the standard for how to structure a successful campaign in the age of internet and social media dominance - detailed databases of voters, micro-targeting of said voters, highly professionalized campaign offices in every state, and millions of dedicated volunteers supporting their candidates either through highly organized social media efforts or a more traditional ground war of knocking on doors, making phone calls, and registering voters. In his primary campaign, Trump was reluctant to rely on the traditional ground war as the GOP party machine was highly suspicious of him and instead he relied on his own fame, the passion of disgruntled voters who responded to his populist message, and Twitter to replace the traditional campaign organization. Hillary Clinton did indeed follow Obama's playbook with a massive ground game, yet eventually Trump's unconventional campaign proved successful. This article explores the populist aspects of the presidential campaigns of Barack Obama in 2008 and Donald Trump in 2016 and how the Trump campaign successfully veered from the dominant narrative of an Obama-type campaign as the accepted standard for winning national elections in the early twenty-first century. However, both candidates' campaign strategies - however different - supported their messages of representing popular movements.

While Barack Obama and Donald Trump occupy opposing positions on the political spectrum, they do indeed address the same problem: the alienation of the American people from their elected officials and growing distrust of political and economic elites. Addressing this dissatisfaction is hardly unique for the Obama and Trump campaigns, but is a mainstay in

1 See www.270towin.com/2016-polls-clinton-trump/ for an extensive overview of national polls, most of which predicted a victory for Clinton.

2 See Confessore and Shorey; Desjardins and Bush; Gabriel 2016; Tankersley 
American electoral politics, particularly on the national level. What they each represent is a different popular solution to a problem of elitist control and centralisation. This article presents a comparative analysis of the campaigns of Obama and Trump, focusing on their respective uses of the internet and social media communication in mobilizing voters and volunteers and using their way of connecting with voters to emphasise their legitimacy as anti-elitist candidates.

While Trump decided not to follow the Obama playbook for winning elections (whether by choice or by necessity), there were significant traits in common between Obama's campaigns (mostly 2008 and, to a lesser degree, 2012) and Trump's 2016 campaign. Both relied on rhetoric inspired by American populist traditions and the public dissatisfaction with the status quo in Washington, both candidates ran as political outsiders, and, finally, both campaigns renewed or reinvented ways of communicating with potential voters and mobilizing volunteers. While Obama combined traditional campaign methods with an innovative twist in the shape of an internetbased campaign, Trump decided to forego the party-based organization for much of his campaign. Instead he relied on a combination of social media communication and grassroots-based volunteering, often circumventing the organization of the GOP. As both the Obama and Trump campaigns illustrated, the democratic potential of the internet lies in ability to reach voters directly with very little cost to the campaign, giving it great potential for reaching, supporting or even creating popular mass movements. By communicating directly with voters, candidates with great online presence can claim to connect directly and personally with voters, circumventing "elitist" institutions, such as the traditional media or even their own party (such as the case with Trump who, during his primary campaign, was not on good terms with the Republican Party.) The message of the campaigns and their method of mobilizing and communicating with voters were thus mutually supported. The message and the carrier of the message served the same end.

\section{American populism(s)}

The term "populism" remains highly contested and the subject of widespread debate within the field of political history, philosophy, and political science. The re-emergence of populism as global mass movements in the early twenty-first century has renewed interest in the topic and its defini- 
tion. ${ }^{3}$ Despite the problems of definition, many scholars can agree that while populism varies geographically, especially when comparing the US and Europe, yet there remains certain global trends. ${ }^{4}$ This article relies on Bonikowski's claim that populism is not an ideology, but rather a rhetorical framework making it a tool by both the left and the right. "The people" is seen as the embodiment of democratic values and the common good whereas elites are considered to be self-serving and morally corrupt. ${ }^{6}$ Furthermore, according to Mudde and Kaltwasser populism is based on society being divided into "two homogeneous and antagonistic groups, "the pure people" and "the corrupt elite". Mudde and Kaltwasser acknowledge that populism is "a thin centred ideology" - the many historical and national differences between populist movements make wide-sweeping definitions difficult. Furthermore, attempts at this often led to conclusions that very few politicians and movements who either claim to be - or are accused of populist - are truly populist. ${ }^{7}$

Populism juxtaposes "the common man" or "the people" with elites. Those frequently identified as "elites" are politicians, big business, special interests, civil servants/bureaucracy, the media, members of academia, although the threat to popular interests and representation often vary according to other ideological considerations. Müller points out that populism historically has been a left-wing phenomenon in the US, the idea of left-wing populism in Europe has a much weaker history. ${ }^{8}$ At times religious and/ or ethnic minorities are considered co-conspirators in this threat to society and equal opportunity of "the people." By relying on populist traditions or rhetoric, politicians can present themselves as the leader of popular movements, fighting for the interest of disenfranchised or un-included groups

Many national politicians in American politics campaign against Washington, promoting themselves as representing the interests of citizens rather

3 Jan-Werner Müller, What is populism?, (Philadelphia: University of Pennsylvania Press, 2016) is a popular and recent example

4 Müller; Cas Mudde and Cristóbal Rovira Kaltwasser, eds., Populism in Europe and the Americas: Threat or Corrective Democracy (Cambridge University Press, 2012).

5 Bonikowski pp. 12-14

6 Kazin 1995 p. 1

7 Mudde and Kaltwasser p. 8; see Müller for an example of a definition of populism that significantly narrows the field of politicians and movements could can genuine claim populist credentials

8 Müller p. 8

9 Bonikowski p. 10 
than American elites. Those citizens can be defined by their economic hardship, social class, staus as racial or ethnic minorities or other signifiers of differentiation, but similar for all is that they are presented as un-represented in the elitist game of distributing power - often political or economic power. This oft-used tool of "running against Washington" reflects the significance of America's revolutionary past and historical legacy of popular movements in favor of decentralisation and democracy to the nation's political identities, on both sides of the political spectrum. One characteristic of American populism independent of liberal or conservatives leanings, according to Michael Kazin, is the argument that the "people" is the embodiment of the American creed, of the nation's true legacy of democracy and equal opportunity. ${ }^{10}$ Populism in the US has been used to describe movements that incorporated traditions of producerism, anti-intellectualism, antielitism, Americanism (nativism), majoritarianism, and moralism (often an extension of evangelical movements). ${ }^{11}$

The American populist traditions argue in favor of returning the power of decision making and agenda setting to the American people, a combination of historical trends of inherent distrust of elitist institutions and a contemporary reaction to the political polarization and centralization of political and economic power. ${ }^{12}$ American populism have histories on both the left-wing and the right-wing, just in the recent decade the left-wing Occupy Wall Street grew in reaction to the elites of Big Business and Wall Street, while more right-wing Tea Party Movement protested the federal bureaucracy and inefficient of Washington, D.C. The left-wing and right-wing versions of populism were juxtaposed in 2016 as Trump's right-wing populism was counterpointed by the left-wing populism of Bernie Sanders who attacked Wall Street and America's wealthiest citizens for destroying the prospect of equal opportunity. Advocating for universal healthcare, amongst other initiatives frequently attacked for being "socialist" in the American context, Sanders mobilized voters who felt frustrated by the lack of accountability by the economic elite that had created the 2008 recession, but failed to win his party's nomination.

\section{Kazin 1995 p. 12}

11 This list was compiled by Berlet, based on various sources on populism as an American phenomenon. See Chip Berlet, "Reframing Populist Resentments in the Tea Party Movement" pp. 109-150 in Lawrence Rosenthal and Christine Trost, eds., Steep: The Precipitious Rise of the Tea Party (Berkeley: University of California Press, 2012), pp. 131-132.

12 Dulio and Klemanski p. 44 
In the American context, the term populism is frequently defined according to its relation to the Populist Party, founded in 1892, had its base in the South and Midwest and was a reaction against the corporate power threatening the livelihood (and by extension "The American Dream") of ordinary Americans ${ }^{13}$ The rise of rural populism was increasingly white (and to a lesser degree male). The populist movement of the late $19^{\text {th }}$ century can be understood as the inspiration and intellectual foundation for populist movements on separate parts of the political spectrum - socialism/labor movements, and the evangelical movement that to this day remain a crucial part of the Republican Party. ${ }^{14}$ This identification of "populism" with the political movement of the 1890s has, according to Müller, created the illusion that this movement was truly populist. Instead, Müller defines populism as a moral, anti-pluralist claim putting the power in the hands of the "true people." 15

One of the main characters of this article directly disagrees with this definition: "So let's just be clear that somebody who labels "us" versus "them," or engages in rhetoric about how we're going to look after ourselves and take it to the other guy - that's not the definition of populism." These are the words of Barack Obama who was dissatisfied with frequent references to Trump as a populist during the 2016 presidential campaign. During a joint press conference with the President of Mexico and the Prime Minister of Canada, Obama listed the initiatives he had made to protect the interests of regular citizens and creating equal opportunity ending with "I suppose that makes me a populist." Furthermore, Obama defines populist leaders as those who worked for equal opportunity for all citizens, referring indirectly to Donald Trump as someone "who has never shown any regard for workers, has never fought on behalf of social justice issues or making sure that poor kids are getting a decent shot at life or have health care-in fact, have worked against economic opportunity for workers and ordinary peoplethey don't suddenly become a populist because they say something controversial in order to win votes. That's not the measure of populism. That's nativism or xenophobia or worse. Or it's just cynicism." Instead, Obama singles out Bernie Sanders as a politician who legitimately could refer to

13 Kazin 1995 p. 29

14 Kazin 1995 pp. 3-4; See Elizabeth Sanders, Roots of Reform: Farmers, Workers, and the American State, 1877-1917 (Chicago: University of Chicago Press, 1999).

15 Müller 
themselves as populist. ${ }^{16}$ In the campaign rhetoric of Obama and Trump, there should be less focus on the proper academic definition of a term, and how those candidates considered themselves related to what they and their supporters considered to be populist, or in the interest of "the people."

\section{Two populists?}

Barack Obama would rely on traditional left-wing populism in accusing the GOP of acting in the interest of big business and would return to the same rhetoric in his 2012 reelection campaign. ${ }^{17}$ In reaction to the electoral dominance of the Republican Party in presidential elections since the 1960s, parts of the Democratic Party tried to return to the populist ideas that had influenced the party early in the twentieth century - special intests, particularly Wall Street and Washington lobbyists, were the enemies of public interests. Rather than rejecting the notion of popular power through the federal government, Obama presented government as the answer, but with a populist touch. The other Democratic president to lead the nation though a major economic crisis, Franklin D. Roosevelt, had done something similar in the 1930s by arguing that only through the federal government could the people combat the elites that had created the crisis. ${ }^{18}$ Especially in the economic matters where the recession was, according to Obama, caused by "the speculators on Wall Street who gamed the system and the regulators in Washington who looked the other way." 19 But as with both Clinton in 1992, coming to power after three terms of Republican control of the White House, and Obama in 2008, after two terms of George W. Bush, Democratic messages have found greater resonance with voters after several years of conservative domination.

"The people" of Obama's rhetoric was more racially and ethnically inclusive than much of various populist traditions which were often identity with the nation's white majority. Obama frequently emphasized the contributions to his campaigns by women, young people and people of col-

16 Barack Obama, The President's News Conference With Prime Minister Justin P.J. Trudeau of Canada and President Enrique Peña Nieto of Mexico in Ottawa, Canada, June 29, 2016 The American Presidency Project https://www.presidency.ucsb.edu/node/318181

17 Rhodes and Johnson pp. 111-113

18 Bloodworth 2017 p. 46.

19 Obama, September 28, 2008 
or. ${ }^{20}$ Furthermore, rather than exclusively blaming the GOP or special interests, Obama called on voters to become more civically engaged. The focus for this civic revival would be in many instances be the American government. While Democrats in later decades as bought into Republican rhetoric of government being the enemy, Obama was pro-government. Not as an alternative to civic and voluntary action, but as their supporter and as an expression of the common good. He argued that "for our country to succeed, Washington has to change. Because at moments of great economic transformation, government must serve as a catalyst for change. ${ }^{21}$ He rejected conservative claims that his policy was socialist by claiming that "I call it opportunity, and there is nothing more American than that." 22 Obama's campaign manager David Plouffe argued that electoral success was achieved because "It was not his campaign - it was their campaign". ${ }^{23}$ Obama's message of civic engagement, pluralist policies and references to his educated background might make him fall outside the category of populist politicians according to some scholars, but according to the leftwing historical tradition and Obama's own insistence of populism being by definition inclusive his approach was one truly representing the American people and the American creed. ${ }^{24}$

Obama would use his pre-politics life to emphasize his credentials as leader in touch with the public. He had served as a community organizer in Chicago, prior to pursuing a political career thus signifying he had experience beyond the halls of Washington in handling "real" problems. Obama rose to prominence at the 2004 Democratic convention when he gave the keynote address, "The Audacity of Hope." In the highly partisan and divisive atmosphere of the Bush years, this charismatic community organizer called for unity and bipartisanship. Obama proposed a new vision of America based on the idealistic notions of equality opportunity and the concepts of the common good. Obama as a person also emerged as a symbol of a different kind of America - multicultural, biracial, cosmopolitan. His identity as African-American would contribute to the populist tone of the 2008 campaign as serving as a community organizer in Chicago provided him

20 See e.g. Obama, June 3, 2008

21 Obama, June 26, 2008

22 Obama, October 27, 2008

23 Plouffe p. 380

24 For a scholar that does not view Obama as a populist, see Müller pp. 20, 76-78. 
with a connection to the traditions of organization in the African-American community. ${ }^{25}$ Grassroots organizing was of crucial importance to black history and identity, and Obama faced the challenge in the 2008 election that he needed to mobilize the African American communities. By employing grass roots methods, so significant to black history and progress, he could address black voters both in method and message. ${ }^{26}$

In both his 2008 primary campaign against Hillary Clinton and, later, against Republican John McCain, he challenged the business as usual approach. He claimed that America needed solutions inspired on the community-based efforts by everyday citizens, not partisan bickering in Washington. The populist sentiments of Obama's campaign especially resounded with voters due to the recession of 2007/2008 that portrayed the GOP leadership as complicit in the crisis and lacking in sustainable solutions. Yet Obama often attacked his opponent John McCain for his complicity in the GOP's assumed plan to make the richest Americans even richer at the expense of the middle class. A 13-minute video was sent to Obama supporters, using the 1989-1991 Keating Five Scandal, in which McCain was accused of corruption, to emphasize his presumed lack of ethics. ${ }^{27}$ Presenting the GOP as the party of big business, Obama relied on traditional left-wing populism and would return to the same rhetoric in his 2012 reelection campaign. ${ }^{28}$

Anup Kumar argues that Obama's rhetoric presented a positive and unifying message of "hope" and "change", but also that those terms were ultimately "empty signifiers" which were vague enough for the media and voters to assign them own personal meaning..$^{29}$ However, both emphasized the participation and centrality of "the people" in defining and executing a popular movement. Obama's rhetoric mostly addressed two issues - the restoration of public trust in politics by creating a populist, transparent mode of government which would favor the American people rather than lobbyists or special interests and second, bridging the increasingly volatile divide between Republicans and Democrats. The enemies in Obama's populist scenario were those forces that had violated the ideals of Ameri-

25 See Kloppenberg

26 Ford, Johnson and Maxwell p. 262

27 Mike Allen, "Obama to hit McCain on Keating Five", October 5, 2008, politico.com,https:// www.politico. com/story/2008/10/exclusive-obama-to-hit-mccain-on-keating-five-014302

28 Rhodes and Johnson pp. 111-113

29 Kumar p. 5 
can social justice and decency. These forces had led America into the Iraq War and 2007-2008 recession. Obama's populism was less outspoken that Trump's would be eight years later and identified quite different targets than Trump. Most of the time, anyway. Both Obama and Trump talked of working against the special interests, lobbyists and big business interests that tempted elected officials away from voting and acting in favor of their voters. Despite Obama's promise in 2008 to limit the access of special interests and lobbyists to lawmakers, Trump would later be successful in painting Obama as another out-of-touch and tax-and-spend liberal member of the federal conspiracy against the "true" American people. While this was possible due to the right wing's identification of Obama as urban, nonwhite, and potentially an-American. But Obama also faced the problem of being a victim of his own electoral success. Promising to reform "the system" is quite differently when you are identified as the figurehead of the system (as any POTUS will unavoidably be). According to Michael Kazin, other presidents with populist campaigns faced the same issues, independent of party identification. While both Richard Nixon and Ronald Reagan rallied against the federal government and the liberal establishment in their campaigns, their populist criticism greatly diminished once they were actually in power. The distance from populist rhetoric to populist policy grows greatly once electoral success has been achieved." ${ }^{30}$ Most significantly, Obama presented the American government as part of the solution to the economic crisis, making one of the institutions most frequently attacked in populist rhetoric the source of unity and problem-solving. Obama was fundamentally pro-government, but argued it had been tainted by lobbyists, big business, and the selfish, electoral interests of the increasingly polarized parties. ${ }^{31}$

After decades of the Republican Party monopolising patriotism and "real" American values (rural, white, working, Christian), Obama "made it cool - even hip - for liberals to love their nation." ${ }^{32}$ Obama redefined American values as multicultural, educated, and urban as a response to the conservative strategies to identify patriotism with rural, white Christians. The GOP counted Obama's claim of representing a broad spectrum of Americans with the appearance of Joe the Plumber - the kind of aver-

30 Kazin 1995 p. 265; Bonikowski p. 15

31 See e.g. Obama, October 15, 2008

32 Bloodworth p. 47 
age (white) American that could not identity with the biracial, Ivy-League educated Obama. Instead his populism united young voters, ethnic and racial minorities, and the urban middle class. But Obama refused to identity certain parts of the population as scape goats: "There are no real or fake parts of this country. There is no city or town that is more pro-America than anywhere else" 33 - the threat to American values came not from certain social or ethnic groups, but special interest groups. Rather than identifying and blaming certain groups - ethnic or social - as Trump would later do, Obama relied on a more inclusive notion of "the people", defined by a common dedication to social justice and good government. According to Jeff Bloodworth, demographics allowed Obama to finally create a winning coalition from these groups - the Democratic Party had been moving away from traditional white, rural populism for decades, but only in 2008 did demographic changes allow for a victory. ${ }^{34}$

The greatest departure from traditional American populism (as signified by the Populist Party of the 1890s) to the Republican Party of today, including Trump, is that big business is no longer the main enemy, but rather the federal bureaucracy, the media, and the academic community. ${ }^{35}$ Instead Trump has taken a page from the 1992 campaign of independent candidate Ross Perot in which he promised to "run America like a business." ${ }^{36}$ Business and its method became the solution to fulfilling populist aspirations. Trump would indeed attack big corporations for sending jobs abroad and neglecting the American workforce, but his solution was the apply the lessons from running the Trump Organization to the federal government. ${ }^{37}$ Trump's rhetoric focused on how elitist - government, media, corporations - had abandoned the values and interests of the American people. At times Trump even included the Republican Party in this alliance, especially during the primary season when the leadership of the party did little to hide their dissatisfaction with the Trump campaign. When Trump spoke of how "this Washington establishment will stop at nothing to stop all of us" he was referring to all elites, also conservative ones. ${ }^{38}$ This even included attacks 
on the judiciary system and the democratic role of the media - a characteristic of the more aggressive versions of populism. ${ }^{39}$

The embodiment of this corrupt elite was his opponent, Hillary Clinton who he claimed "is an insider fighting only for insiders I am an outsider fighting for you." ${ }^{40}$ In fact Clinton and her husband (the former president) could be blamed for most evils in society: "the Clintons robbed Pennsylvania, stole your jobs, and shipped them to other countries." ${ }^{41}$ Trump promised, on the other hand, to "end the Clinton Corruption." 42

Donald Trump was an even greater outsider in American politics than Obama as he had never run for a public office before nor had he served in any level of government. By the end of Obama's second term as president, the partisan deadlock that he had promised to end had become even greater. Trump could easily claim to provide an alternative to the political environment as he had never been part of it. In fact, he would be the only candidate who could help America return to its creed as all aspects of American leadership (political, financial, intellection was corrupt, stating:

They're all part of the same political establishment. They go to the same restaurants, they attend the same conferences, they have the same friends and connections. They all support the same ideology of globalism that makes them rich while shipping your jobs, your factories, and your wealth to other countries. ${ }^{43}$

His total outsider status combined with his reputation for "getting things done" made him appealing to voters feeling totally disillusioned by the political process. Trump also relied on his previous career in creating his campaign. Despite by primarily known as a businessman, it was his background in the entertainment industry that would define his campaign. Over the years, Trump built an entertainment empire based on his name rather than his business efforts. His TV show The Apprentice had not only introduced him to a wide public audience, but had also created the image of Trump as a no-nonsense, successful business man with a knack for "getting things done." 44 Despite not having any political experience, Trump had already

39 Bonikowski p.11

40 Trump, September 28, 2016

41 Trump, September 22, 2016

42 Trump, September 28, 2016

43 Trump, September 22, 2016

44 Cornfield p. 14 
developed a report with members of the populist right in America. He had served as the most public proponent of the birther-movement, claiming that Obama lied about having been born in the US. From the birther-movement arose the Trump candidacy. The basis for Trump's populist rhetoric was a deep-seated distrust of any and all elitist institutions, from the political and federal institutions in Washington, to the national media and the judiciary system. Furthermore, Trump's populism also reacted to the multicultural Obama campaign as his campaign attracted support from several sources on the extreme right..$^{45}$ Trump's populism, both in message (attacks on the federal establishment with racist undertones) and in organization, owed much to the Tea Party Movement. It had challenged GOP leadership on conservative issues in local elections, proved the power of right-wing grassroots, and even counted a considerable number of former Obama voters amongst their ranks. ${ }^{46}$ The Tea Party Movement proved that passionate grassroots activists could unite unlikely allies and that the institutional dominations of established parties could be challenged.

Another threat to the interests of the American people was the media which was not only out of touch with "regular" Americans, but actively in favor of Clinton and liberals. Trump argued that "the Clinton Machine and the Corporate Media are one in the same - they collaborate and conspire together." 47

Trump's populist rhetoric was based on the right-wing idea the greatest threat to American life comes from an alliance between the federal bureaucracy and the so-called liberal elite who support abortions, gay marriage, stricter gun laws, secularisation, and multiculturalism, i.e. enemies of both political and moral order. He frequently identified certain groups as threats to the American society, especially immigrants who supposedly threatened not only the jobs of hard-working Americans, but also their personal safety. ${ }^{48}$ Trump relied here on the Jacksonian tradition of populism in which patriotic Americans are under attack from those trying to undermine its European, nationalist foundation.The ${ }^{49}$ success of populist, conservative rhet-

47 Trump, October 13, 2016

48 See e.g. Trump, Ocobert 28, 2016

49 Walter Russell Mead, "The Jacksonian Revolt: American Populism and the Liberal Order", Foreign Affairs, March/April 2017, pp. 2-7. 
oric of the last half-a-century was due to the marriage of the fears of economic conservatives (big government) and the fears of social conservatives (moral decline).$^{50}$ With campaigns slogans such as "Make America Great Again" and "America First", the Trump campaign was direct response to Obama years and the promises that he had failed to keep in his eight years in office. Trump argued that his campaign was "a testament to all of the people who believed real change, not Obama change, but real change is possible." ${ }^{51}$ Obama himself became the target of the wrath of right-wing populist in the birther movement, led by Donald Trump even before his entry into electoral politics, in which Obama's otherness was translated into disloyalty and even a deliberate deception of the American public. During his 2008 campaign Obama had described small-town voters in Pennsylvania as clinging “to guns or religion or antipathy to people who aren't like them or anti-immigrant sentiment or antitrade sentiment as a way to explain their frustrations." 52 For right-wing populists, statements such as this made Obama an easy target to portray as elitist, intellectual, and too urban. Barely hidden under the birther movement and the MAGA slogan were notions of white supremacy and a reaction against the increasingly multicultural character of American society. ${ }^{53}$ Millions of Americans felt overlooked by national politicians and ignored by the national media. Even Trump's own language and character contributed to his populist appeal. His informal, at times inappropriate language, in Twitter updates and his improvisational style at rallies fed into the notion of Trump as a man who spoke the language of the public. He frequently relied on angry rhetoric such as promises that "the arrogance of Washington, D.C. will soon come face to face with the righteous verdict of the American voter". ${ }^{4}$

\section{Campaigning in the internet age}

As voter participation and party identification have both declined in the last half century, political parties and candidates are dependent on mobiliza-

52 Katherine Q. Seeley and Jeff Zeleny, "On the defensive, Obama calls his words ill-chosen”, The New York Times, April 13, 2008, Online, https://www.nytimes.com/2008/04/13/us/ politics/13campaign.html

53 Kazin 2016 p. 17

54 Trump, September 22, 2016 
tion of voters and turnout rates. Presidential campaigns are dependent on massive budgets, national strategies, orchestrated televised and print advertising, all run by hundreds of paid professionals who approach winning elections as a scientific, rational process. Yet turn-out remains influenced by direct contact between the campaigns (often with volunteers representing the campaign) and potential voters. Direct, personal contact between the campaign and the voter is so powerful that it can compensate for limited campaign finances and access to traditional media.$^{55}$ Media has consistently through history defined and redefined how American politicians and political parties communicate with voters and mobilize them as a resource, not just electorally, but also organizationally. The internet, the latest technology to impact the political and electoral process, has "enabled American citizens to easily join any type of political or special interest group" ${ }^{56}$ The easy-to-access information and forums of political debate have proven especially influential in political campaigns of a populist nature. The Obama and Trump campaigns used the internet and particularly social media to spread populist messages while emphasising the populist nature of the online campaign itself. This technology allows candidates to fewer resources on some traditional campaign strategies (such as television advertising) and to strengthen other aspects of the traditional campaigns, such as the volunteer-based ground war. The mobilization of grassroots organization and other potential sources of campaign volunteers has been strengthened by the internet. ${ }^{57}$ The purpose of a candidate's online presence is not just to spread information about the campaign, but to mobilize voters. Whereas traditional media such as print and television can spread information and reinforce voters' sympathies, the internet had the added benefit of directly mobilizing voters and turning them into, in some cases, volunteers or at least active agents for the campaign. ${ }^{58}$

Bill Clinton in 1992 was the first presidential candidate to use the internet to reach voters, but it was not until Howard Dean's unsuccessful bid for the 2000 Democratic nomination that the internet was considered a serious weapon in reaching voters, mobilizing volunteers, and raising donations. ${ }^{59}$

55 Nickerson p. 269; also, see Shea and Burton

56 Carpenter p. 217

57 Nickerson p. 280

58 Owen and Davis, p. 18

59 Owen and Davis pp. 1-3; Hendricks and Denton p. 4 
Furthermore, that campaign led to new interest in the Democratic voter database which would play a significant part in the 2008 and 2012 elections. ${ }^{60}$ Obama and his team chose to create their own volunteer network independent of existing the DNC organizations. Not only did this allow Obama more flexibility, but also gave freedom to the campaign's volunteers who came from a much wider group than the Democratic Party's traditional organizations. While professional consultants still directed the campaign's efforts, volunteers were given great responsibilities and attracted many who would otherwise feel unwelcome in the Democratic establishment. ${ }^{61}$

The internet, and particularly social media, allowed for campaigning to circumvent the traditional ground game: McDonald and Schaller argued that "a campaign no longer needs an office to have a substantial presence; it just needs a volunteer with an Internet connection." ${ }^{2}$ The decline of print media and viewership of national tv stations provided campaigns with the opportunity to target more limited audiences with more direct messages. ${ }^{63}$ The rise of television as the major tool of communication between candidates and the voting public made politicians less dependent on the party machinery, yet also made candidates highly dependent of affording the high cost of television ads.

Online technology allows each campaign to create databases of potential voters and target them individually. ${ }^{64}$ Likewise, the mobilization and organization of volunteers have become faster and easier as online tools provided an inexpensive, direct line of communication between campaign and volunteer with little funding or requirements for personal contact. Research has demonstrated a link between political participation on the internet and in campaigns and electoral participation. ${ }^{65}$ The internet has also expanded the opportunities for fundraising; notably, Republican John McCain in 2000 and Democrat Howard Dean in $2004 .{ }^{66}$ In his 2008 campaign, Obama decided to forego federal campaign funding and instead rely on online donations from individuals. In the month of February 2008 alone, he raised 
55.4 million dollars, most of it in contributions less than 200 dollars. ${ }^{67}$ This also allowed for Obama's campaign to appear more populist than traditionel campaigns. By refusing to rely on federal campaign funding, Obama could present his campaign as a true movement of the people: "I' $m$ the only candidate in this race who can say that Washington lobbyists do not fund my campaign, you do." ${ }^{68}$

\section{The Obama Campaign}

A study by Seth E. Masket suggests that Obama's superior ground game might not have determined the outcome of the election, but rather increased Obama's majority - especially in swing states. The campaign's high level of volunteer organization boosted the Obama vote by more than 3 points in some states. ${ }^{69}$ Despite the innovative use of online mobilisation, the Obama campaign did not neglect the traditional ground game. Instead the internet and local field offices complemented each other. Obama himself argued that he chose a community-based campaign because "I was always confident about, was that if people will to submerge their own egos, and bring their particular gifts, passion, energy, and vision to a common task, that great things can be accomplished. That's my old organizing mindset." ${ }^{70} \mathrm{He}$ told voters that "if you want real change (...) then I ask you to knock on some doors, make some calls, talk to your neighbours." 71

Obama's extensive campaign organization, was inspired by concepts from community organizing combined with internet activism and online networking. Trump personally used Twitter to communicate with voters while the campaign itself relied on un-organized volunteers to spread the word-of-mouth. Obama's 2008 was the first to fully utilize the power of the internet. It provided the Obama campaign with a method of knowledgesharing and mobilization of voters and volunteers that bypassed the traditional party machinery. Through file sharing, networking on social media, and the use of visual online media (such as Youtube), the Obama campaign reached potential voters directly. Furthermore, the collaborative nature of 
many of these sites made an outstanding opportunity for Obama supporters feel that they could make a difference in the campaign. The campaign's mantra was "respect, empower, and include."72 Obama relied on previous experience with social media in Democratic Party campaigns although the full potential of the internet had not yet been explored by either party. With an online network of 13 million registered supporters, ${ }^{73}$ Obama had built a national movement ready to share campaign messages, contact potential voters, and mobilize volunteers. The online strategy was reflected in the Obama campaign many local campaigns offices with Obama's 700 nationwide field offices dwarfing McCain's 400. And yet, they managed to spend fewer financial resources on these activities than McCain's campaign due to volunteer efforts. ${ }^{74}$

Obama's rhetoric found a particularly eager audience in young voters. This coincided with the overrepresentation of young Americans amongst users of social media. ${ }^{75}$ By emphazising his own use of modern technology, Obama appealed to young voters who felt uneasy with traditional media and special interest groups. Grassroots organizations of the future would be online, and Obama's campaign understood this. Obama supporters found a new online community on MyBO, a website connecting potential voters. McCain, on the other hand, admitted not being comfortable with emails and called himself a "digital illitterate." 76

An example of how the Obama campaign mobilised voters and volunteers was an app which gave the user information about volunteering activities, such as nearby rallies or phone banks. ${ }^{77}$ This also opened up for a new type of campaign volunteers: previously volunteers would man phone banks, hand out yard signs or register voters, but now they could contribute to the campaign anytime, anywhere. These volunteers extended the Obama online campaign, sometimes directed by the campaign, other times individually and spontaneously. Youtube, Facebook, blogs and the online community MyBO were the main channels of communication. Texting was used to connect to voters less likely to use the internet. Obama could mobilize first-time voters, and using social media and viral technology was par-

72 McKenna and Hahrie p. 51

73 Ford, Johnson, and Maxwell p. 471

74 Luo and McIntire

75 Baumgartner and Morris p. 61

76 Kestenbaum

77 Cogburn and Esoinoza-Vasquez p. 202 
ticularly effective to reach young voters. Furthermore, the internet proved to be a campaign tool that requires little funding or professional guidance and is easily accessible. ${ }^{78}$ Obama's volunteer army became of crucial importance for his electoral success; by emphasizing the individual contributions and encouraging volunteering for the campaign rather than simply voting, Obama created a national movement where many felt that they had a personal stake in the victory. ${ }^{79}$ Republican strategist Gary Jarmin found Obama's "unprecented ground game" to be the determining factor in the election and warned "never underestimate the dedication and passion of volunteers and contributors who believe they are in the process of making history - it can be an incredibly powerful motivation." 80

\section{The Trump Campaign}

By the 2012 election, these innovative campaign methods had been accepted by the Democratic Party as the standard for winning elections. Obama's reelection, with grassroots aspects of the campaign becoming more professionalized, suggested the continued success of the strategy. Between 2012 and 2016, the significance of the internet was increasingly consolidated, especially as a platform for accessing visual media (images and videos) and news about the politics and the election. ${ }^{81}$ By 2016, the Republican Party had also accepted the Obama campaign as the new gold standard, but was stunned by the electoral success of Donald Trump. Obama had transferred his experience as a community organizer to a national campaign; now Trump did the same with his experience as a media icon. Journalist Sasha Issenberg argued that Trump "sees his candidacy as an extension of the mechanism of becoming a celebrity." 82 While Obama explored the potential of the internet in his 2008 and 2012 campaigns, by 2016 Donald Trump found social media, particularly Twitter, to be his primary channel of communication with the American voters. Furthermore, internet use became far more widespread among all generations, but particularly among the older generations. Whereas the internet and social media in particularly had been directed more at the younger generations in 2008, Trump could

78 Ford, Johnson and Maxwell p. 470

79 Levenshus p. 333

80 Jarmin

81 Enli pp. 50-51

82 Quoted in Tankersley 2016 
take advantage of older generations (more likely to vote Republican) having access to other media channels than tv and print. ${ }^{83}$

In the primary elections, Trump faced an uphill-battle against the GOP leadership that distrusted him, and he faced superior election organization from other Republicans, especially Ted Cruz. ${ }^{84}$ The party itself became the target of Trump's populist anger as the candidate accused the party of trying to steal the nomination from him by swaying delegates going into the convention. ${ }^{85}$ In the national campaign in the fall of 2016, the Trump campaign and the GOP tried to work more closely together. ${ }^{86}$ Accepting that Trump was their nominee, the party set out to match the campaign organization by Hillary Clinton and the Democrats. The 2012 Obama reelection campaign served as their main inspiration. ${ }^{87}$ This was made difficult by Trump entering the national election with as little as 70 professional campaign staff members, compared to Clinton's more than 700 professionals ${ }^{88}$ Trump and his core campaign staff focused on television and social media outreach, while the RNC instead focused on the ground game particularly in crucial states, such as Ohio. ${ }^{89}$ The Trump campaign recognized that rejecting the traditional campaign rulebook highlighted the populist message and appealed to voters. ${ }^{90}$

The representation in the national media of the ground game of the Trump campaign as being almost non-existent, or poorly organized at best, frustrated campaign operatives. ${ }^{91}$ But the Trump campaign did indeed have a ground game, even if it differed from the traditional style. It was decentralized and based on local, rather than national strategies. In Georgia, in the primary election season, the Trump campaign only had five paid campaign officials, but grassroots volunteers were active in all the state's counties. A leading GOP strategist in the state said that "people who don't think we have a ground game will be surprised".$^{92}$ As volunteers organized beyond

\footnotetext{
83 Vogels

84 Gabriel 2015

85 Easley

86 Gold; Haberman and Healy

87 Gold

88 Gold

89 Hulsey; Kraus and Opilo

90 Haberman and Healy

91 Jacobs 2016a

92 Redmon
} 
the grasp of the RNC strategy or out of sight of the national media, their presence was easily overlooked or underestimated. Furthermore, the usual suspects of the Republican ground game - social conservatives and evangelicals - were at first slow to come out for Trump - and thus their absence from the early suggested that the Trump campaign had failed to mobilize the grassroots. Instead, the Trump campaign focused on mobilizing newcomers to grassroots politics, including first-time voters or frustrated Democrats, ${ }^{93}$ at times causing conflicts with the RNC paid staff who were upset by the Trump staffers bypassing the campaign offices and communicating directly with voters. ${ }^{94}$ What the Trump campaign lacked in organization was compensated for by voter enthusiasm. ${ }^{95}$ Trump convinced his voters that "to beat the system, you have to lift your voice, pound the pavement, and get out the vote". Trump's ${ }^{96}$ vice-presidential candidate Mike Pence argued that "all the website stories and tweets and Instagrams don't matter to a hill of beans to the impact that you can have sitting down with a friend who knows you, who respects you and telling them how important it is that Donald Trump is the next president of the United States." 97 The Trump campaign would encourage voters to talk to friends and family and promise to personally endorse the candidate. At rallies, supporters were asked to sign a pledge to support Trump, give their addresses and phone numbers and to sign up as volunteers for future rallies. This was hardly the high-tech datamining of the Obama campaigns, but it created a personal touch between the Trump campaign and potential voters. ${ }^{98}$ The distrust in the traditional print and television media encouraged Trump's use of Twitter. He named the media as one of the enemies of the people and instead used social media as a channel of communication rather than tv or print coverage. Several studies from Pew Research Center illustrate how support for Trump strongly correlates with distrust of the media in general. ${ }^{99}$ The candidate's use of Twitter coincided with historic change in how and where Americans get their news, giving ample opportunity for Trump to take advantage of the right-wing populist notion of the media as elitist.

\footnotetext{
93 Jacobs 2016a

94 Jacobs 2015

95 Krauss and Opilo

96 Trump, September 22, 2016

97 Quoted in Hulsey

98 Jacobs 2015

99 Gottfried et.al.
} 
While the improvised, uncensored tweets from Trump seemed to reveal a candidate with few boundaries, this sense of direct action, of unfiltered honesty appealed to the voters who distrusted the so-called liberal media. As the media and academia have become some of the favorite targets of right-wing populists, this group is particularly susceptible to alternative media. ${ }^{100}$ While social media in the 2008 Obama campaign highlighted its appeal to young people, the 2016 Trump campaign illustrated how social media serves as an alternative source of not just organization, but also news information. His social media campaign was also less organized than that of the Democrats. Due to the success of online networks in the 2008 Obama campaign, the parties quickly professionalized online technology. As a result, by 2016, the Clinton campaign has a large online presence, but it had lost the aura of authenticity and grass roots action. In contrast, Trump's Twitter account provided direct access to the thoughts and moods of the Republican candidate. While it included controversial instances of Trump attacking political opponents, it also provided voters with a sense of honesty and authenticity. ${ }^{101}$ If Obama had an email network of 13 million people at the time of his victory in 2008, Trump had 17 million followers on Twitter in the fall of $2016 .{ }^{102}$ Furthermore, Trump's personal wealth, insistence of remaining independent of GOP influence, and lack of political experience led to him having a weak fundraising strategy. For a campaign lacking in funds, the two primary methods of promoting Trump were costsavvy: the candidate addressing his supporters directly on social media and the word-of-mouth approach advocated by the campaign. In the end, they proved to be enough for victory. Like his predecessor in the White House, Trump argued that his campaign was financially independent from public financing and rather his campaign was an alliance between his own business acumen and the will of the people: "My campaign is powered by my own money, and by small dollar donations from everyday patriotic citizens. $95 \%$ of our donors are small dollar donations. Every dollar helps us deliver your country back to you." 103

100Kazin 1995 p. 259

101Enli p. 59

102Enli p.53

103Trump, September 22, 2016 


\section{Conclusion}

Barack Obama's campaign for the 2008 election turned into a popular movement, but mobilizing voters as a party outsider required him to combine use of the internet with mobilizing grassroots. This developed into a campaign of meticulous organization and data-oriented strategies that supported a narrative, both in the national media and within the major parties, that this type of campaign was now necessary to secure electoral victory. Eight years later, Donald Trump also combined the internet and grassroots; however, he used his online presence to attract attention, inspire grass roots to mobilize and volunteer, but not necessarily under the umbrella of the national campaign organization. While the RNC had a volunteer network during the fall of 2016, many unorganized grassroots groups working to elect Trump fell outside that network. These groups were at times overlooked in the national media, lending credence to the idea that Trump was solely dependent on his social media presence to mobilize voters. That these grass roots were rarely noticed by the more elitist channels, play into the idea that Trump's populism appealed to Americans who felt overlooked in the national debate. With the success of the Obama campaigns in 2008 and 2012, the DNC tried to copy it for Clinton's 2016 run, but it failed to capture the same public sense of activism and personal ownership. Populist movements depend on a sense of urgency. Because the Democrats professionalized the 2008 strategies in the campaigns of 2012 and 2016, this created an opening for another form of populist momentum led by Trump. He used different means than Obama, yet he still managed to galvanize his voters. A populist movement is a powerful force in electoral politics, but attempts to professionalize it run the risk of losing the public momentum that is essential to success. In the 2012 reelection, the Obama campaign included 2.2 millon volunteers. Despite these impressive numbers, the campaign was criticised for making the campaign too professional, too organized, having lost some of its civic magic. Trump and Obama represented two different version of popular movements, both in different ways inspired by American populist traditions, and by combing them with new ways of political communication and mobilization managed to achieve electoral victory. 


\section{Bibliography}

"2016 Presidential Election Polls.” Online. https://www.270towin.com/2016-polls-clintontrump/

Allen, Mike. "Obama to hit McCain on Keating Five." October 5, 2008, politico.com https://www.politico.com/story/2008/10/exclusive-obama-to-hit-mccain-on-keatingfive-014302 .

Baumgartner, Jody C. and Jonathan S. Morris, "'Who Wants to Be My Friend?: Obama, Youth, and Social Networks in the 2008 Campaign", in John Allen Hendricks and Robert E. Denton, Jr. (eds.), Communicator-in-Chief; How Barack Obama Used New Media to Win the White House, Lexington Books, 2010, pp. 51-65.

Berlet, Chip. "Reframing Populist Resentments in the Tea Party Movement." In Lawrence Rosenthal and Christine Trost, eds., Steep: The Precipitious Rise of the Tea Party. Berkeley: University of California Press, 2012, pp. 109-150.

Bimes, Terri and Quinn Mulroy, "The Rise and Decline of Presidential Populism", Studies in American Political Development, Vol. 18, Fall 2004, 136-159.

Bloodworth, Jeff, “Obama: Urban Liberalism's Ascent”, Politics Symposium, January 2017, pp. 44-48.

Bonikowski, Bart, "Three Lessons in Contemporary Populism in Europe and the United States", The Brown Journal of World Affairs, Volume 23, Issue 1, Fall/Winter 2016, pp. 9-24

Carpenter, Cheris A., "The Obamamachine: Technopolitics 2.0", Journal of Information Technology and Politics, Vol. 7 (2010), pp. 216-225.

Cogburn, Derrick L. and Fatima K. Espinoza-Vasquez, "From networked nominee to networked nation: Examining the impact of Web 2.0 and social media on political participation and civic engagement in the 2009 Obama campaign", Journal of Political Marketing, Vol. 10 (2011), pp. 189-213.

Confessore, Nicholas and Rachel Shorey, "Trump campaign is in deep hole on fund-raising", The New York Times, June 21, 2016.

Cornfield, Michael, "Empowering the party-crasher: Donald J. Trump, the first 2016 GOP Presidential Debate, and the Twitter Marketplace for Political Campaigns”, Journal of Political Marketing, Vol. 16 (2017), pp. 212-243.

Desjardins, Lisa and Daniel Bush, "The Trump campaign has a ground-game problem", August 30, 2016, https://www.pbs.org/newshour/politics/trump-campaign-has-groundgame-problem.

Dulio, David A. and John S. Klemanski, "Parties and Populism in 2016", in C. Rackaway and L.L. Rice (eds.), American Political Parties Under Pressure, 2018, pp. 43-75.

Jonathan Easley, "GOP Reps boosting Trump's insider game in Pennsylvania", The Hill, April 21, 2016.

Enli, Gunn, "Twitter as arena for the authentic outsider: Exploring the social media campaigns of Trump and Clinton in the 2016 US presidential election", European Journal of Communication, Vol. 32, pp. 50-61.

Ford, Pearl K., Tekla A. Johnson and Angie Maxwell, "Yes We Can" or "Yes We Did"?: Prospective and Retrospective Change in the Obama Presidency", Journal of Black Studies, Vol. 40, No. 3 (January 2010), pp. 462-483.

Gabriel, Trip, "Strong in polls, yet Trump lags on the ground", The New York Times, December 20, 2015.

----, “Trump ground game in Iowa lacks a coach", The New York Times, January 14, 2016.

Garcia-Castañon, Marcela, Alison D. Rank and Matt A. Barreto, "Plugged in or tuned out? Youth, race, and internet usage in the 2008 election", Journal of Political Marketing, Vol. 
10 (2011), pp. 115-138.

Gold, Matea, "Trumps leans on party build his national apparatus", The Washington Post, June 11, 2016.

Gottfried, Jeffrey, et.al. "Trusting the News Media in the Trump Era", Pew Research Center, December 12, 2019, https://www.journalism.org/2019/ 12/12/trusting-the-news-mediain-the-trump-era/

Haberman, Maggie and Patrick Healy, "Gingerly, as polls narrow, Trump tries some campaign conventions", The New York Times, January 16, 2016.

Hendricks, John Allen and Robert E. Denton, Jr., "Political Campaigns and Communicating with the Electorate in the Twenty-First Century" in John Allen Hendricks and Robert E. Denton, Jr. (eds.), Communicator-in-Chief; How Barack Obama Used New Media to Win the White House, Lexington Books, 2010, pp. 1-18.

Hulsey, Lynn, “Trump, Clinton set up "ground game” in Ohio", Dayton Daily News, August $15,2016$.

Jacobs, Ben, "Can Trump's top operative in Iowa help the frontrunner live up to his polls?", The Guardian, May 11, 2016a.

----, "Secret sign-ups and TV foot soldiers," The Guardian, October 8, 2015.

----, "Welcome to Iowa", The Guardian, August 28, 2016b.

Jarmin, Gary, "Keys to Obama Victory", The Washington Times, November 7, 2008, https:// www.washingtontimes.com/news/2008/nov/7/keys-to-obama-victory/

Kazin, Michael, The Populist Persuasion: An American History, New York: Basic Books, 1995.

----, "Trump and American Populism: Old Whine, New Bottles", Foreign Affairs, Volume 95, Issue 6, 2016, pp. 17-24.

Kestenbaum, David, "The Digital Divide Between McCain and Obama", August 1, 2018, NPR.com, https://www.npr.org/templates/story/story.php?storyId $=93185393 \& \mathrm{t}=1579009011044$.

Kloppenberg, James T., Reading Obama: Dreams, Hope, and the American Political Tradition, 2010, Princeton University Press.

Kraus, Scott and Emily Opilo, "Volunteers execute the "ground game"”, The Morning Call, October 16, 2016.

Kumar, Anup, "Looking Back at Obama's Campaign in 2008: "True Blue Populist" and Social Production of Empty Signifiers in Political Reporting”, Journal of Communication Inquiry, Vol. 38 (I), pp. 5-24.

Lehmann, Chris, "Donald Trump and the long tradition of American populism", Newsweek, August 22, 2015, http://www.newsweek.com/donald-trump-populism-365052.

Levenshus, Abbey, "Online relationship management in a presidential campaign: A case study of the Obama campaign's management of its internet-integrated grassroots effect", Journal of Public Relations Research, Vol, 22, No. 3 (2010), pp. 313-335.

Luo, Michael and Mike McIntire, "With Ambitious Campaign, Obama is Both Big Spender and Penny Pincher", The New York Times, October 30, 2008, p.8.

McDonald, Michael P. and Thomas F. Schaller, "Voter Mobilization in the 2008 Presidential Election", in David Magleby (ed.), The Change Election: Money, Mobilization, and Persuasion in the 2008 Federal Elections, Temple University Press, 2010, pp. 87-107.

McKenna, Elizabeth and Hahrie Han, Groundbreakers: How Obama's 2.2 Million Volunteers Transformed Campaigning in America, Oxford University Press, 2014.

Masket, Seth E., "Did Obama's Ground Game Matter? The Influence of Local Field Offices During the 2008 Presidential Election", Public Opinion Quarterly, Volume 73, Issue 5, 2009, pp. 1023-1039 
Mead, Walter Russell. "The Jacksonian Revolt: American Populism and the Liberal Order", Foreign Affairs, March/April 2017, pp. 2-7.

Mosk, Matthew, "In Obama fundraising, signs of a shift from online to in-person, The Washington Post, July 18, 2008.

Mudde, Cas and Cristóbal Rovira Kaltwasser, eds. Populism in Europe and the Americas: Threat or Corrective for Democracy? Cambridge University Press, 2012.

Müller, Jan-Werner. What is populism? Philadelphia: University of Pennsylvania Press, 2016.Nickerson, David W., "Quality is Job One: Professional and Volunteer Voter Mobilization Calls", American Journal of Political Science, Vol. 51, No. 2, (April 2007), pp. 269-282.

Obama, Barack, "Barack Speaks to HQ Staff and Volunteers", 2008, https://www.youtube. $\mathrm{com} /$ watch?v=bnhmByYxEIo

----, "Remarks in Canton, Ohio", October 27, 2008, The American Presidency Project https://www.presidency.ucsb.edu/node/284646

---- "Remarks in Detroit", September 28, 2008, The American Presidency Project https:// www.presidency.ucsb.edu/node/284283

----, "Remarks in Green Bay", September 22, 2008, The American Presidency Project https://www.presidency.ucsb.edu/node/285327

----, "Remarks in Londonderry", October 15, 2008, The American Presidency Project https:// www.presidency.ucsb.edu/node/28448

----, "Remarks in Pittsburgh", June 26, 2008, The American Presidency Project, https:// www.presidency.ucsb.edu/node/277917,

----, "Remarks in St. Paul, Minnesota Claiming the Democratic Presidential Nomination Following the Montana and South Dakota Primaries", June 3, 2008 The American Presidency Project https://www.presidency.ucsb. edu/node/277836

- , "The President's News Conference With Prime Minister Justin P.J. Trudeau of Canada and President Enrique Peña Nieto of Mexico in Ottawa, Canada”, June 29, 2016 The American Presidency Project https://www.presidency. ucsb. edu/node/318181

Owen, Diana and Richard Davis, "United States: Internet and Election", in Richard Davis, et.al (eds.), Making a Difference: A Comparative View of the Role of the Internet in Election Politics, Lexington Books, 2008, 19 pp. Ebook.

Panagopoulos, Costas, "Technology and the Transformation of Political Campaign Communications", Social Science Computer Review, Vol. 25, No. 4 (Winter 2007), pp. 423-424.

Plouffe, David, The Audacity to Win: The Inside Story and Lessons from Barack Obama's Historic Victory, New York: Viking, 2009

Redmon, Jeremy, "Georgia's election volunteers", The Atlanta Journal-Constitution, February $26,2016$.

Rhodes, Jesse H. and Kaylee T. Johnson, "Welcoming Their Hatred: Class Populism in Democratic Rhetoric in American Presidential Campaigns, 1932-2012", Presidential Studies Quarterly, Volume 47, No. 1, March 2017, pp. 92-121.

Roth, Benita, "Learning from the Tea Party: The US Indivisible Movement as Countermovement in the Era of Trump", in Sociological Research Online, volume 23, issue 2, 2018, pp. 539-546.

Sanders, Elizabeth. Roots of Reform: Farmers, Workers, and the American State, 18771917. Chicago: University of Chicago Press, 1999.Seeley, Katherine Q. and Jeff Zeleny. "On the defensive, Obama calls his words ill-chosen." The New York Times, April 13, 2008, https://www.nytimes.com/2008/04/13/us/ politics/13campaign.html

Shea, Daniel M. and Michael J. Burton, Campaign Craft: The Strategies, Tactics, and Art of Political Campaign Management, Praeger Publishers, 2006. 
Tankersley, Jim, "Why Donald Trump's 1980-style campaign is struggling in 2016", The Washington Post, August 20, 2016.

Trump, Donald J., "Remarks Announcing Candidacy for President in New York City", June 15, 2015, The American Presidency Project https://www. presidency.ucsb.edu/ node $/ 310310$

----, Remarks at Radisson Armory in Manchester, October 28, 2016, The American Presidency Project https://www.presidency.ucsb.edu/node/326377

---, "Remarks at a Rally at the Mid-America Center in Council Bluffs", September 28, 2016, The American Presidency Project

----, "Remarks at a Rally at Sun Center Studios in Chester Township", September 22, 2016, The American Presidency Project https://www.presidency. ucsb.edu/node/319631

---, "Remarks at the Renaissance Hotel in Columbus", October 13, 2016, The American Presidency Project https://www.presidency.ucsb.edu/node/319610

---, "Remarks of Presidential Candidate Donald Trump after Winning Primaries in Montana, South Dakota, New Mexico, New Jersey and California", June 7, 2016, The American Presidency Project https://www.presidency. ucsb.edu/node/332346

Vogels, Emily A., "Millennials stand out for their technology use, but older generations also embrace digital life", Pew Research Centre, September 9, 2019, https://www.pewresearch.org/fact-tank/2019/09/09/us-generations-technology-use/. 
